International Journal of English Literature and Social Sciences
Vol-6, Issue-5; Sep-Oct, 2021

Peer-Reviewed Journal

\title{
Manifestation of Oedipus Complex in Dh Lawrence's Works
}

\author{
Ibrahim Yekini, Alidou Razakou Ibourahima Boro, Fayçal G. J. Adechokan \\ ${ }^{1,3}$ University of Abomey Calavi, Benin \\ ${ }^{2}$ University of Parakou, Benin
}

Received: 18 Sep 2021; Received in revised form: 18 Oct 2021; Accepted: 24 Oct 2021; Available online: 31 Oct 2021

(C2021 The Author(s). Published by Infogain Publication. This is an open access article under the CC BY license (https://creativecommons.org/licenses/by/4.0/).

\begin{abstract}
Environment and current situation or thought a man finds himself at any time affect his psyche. The ancient Greeks associate psyche with Eros and both form the allegory of life. As love combines psyche and Eros, it links Oedipus complex and Electra complex to some forms of love such as ludus, mania or storge. The manifestation of this complex in Sons and Lovers is observed under the lens of psychoanalytic theory to pinpoint illustrations of desire for sexual involvement with any parent of opposite sex. The current research aims at enlightening the dangerous drawbacks linked to such a relationship between son and his mother. It is observed that the Oedipus complex qualifies Paul's relationships with his mother and with other women mainly, Miriam and Clara.
\end{abstract}

The Freudian theory and psychoanalytic theory will be used to analyze the issue on the protagonist Paul as well as on his mother Gertrude in Son and Lovers and other novels by DH Lawrence.

Keywords-Oedipus complex, transference, ambiguity, mania, Love.

Résumé - L'environnement ou la situation dans laquelle un homme se trouve à certain moment affect son psychisme. La Grèce antique associe le psychisme à Eros (Dieu Grecque de l'amour) et ensemble ils forment l'allégorie de la vie. Comme l'amour combine Eros et le psychisme, il relie le complexe d'oedipe et le complexe d'Electre à d'autres formes d'amour comme Ludus, manie, ou storge. La manifestation de ce complexe dans Sons and Lovers est observée en utilisant la théorie psychanalyse pour souligner les illustrations du désir sexuel avec les parents du sexe opposé. La présente étude vise à souligner les conséquences relatives à une relation du genre entre l'enfant (garçon) et sa mère. Il a été souligner que c'est le complexe d'odipe qui définit la relation de Paul avec sa mère et avec les autres femmes principalement Miriam et Clara.

La théorie Freudienne et la théorie de la psychanalyse sont les théories utilisées pour analyser le problème de Paul ainsi que celui de sa mère Gertrude dans Sons and Lovers et dans d'autres romans de DH Lawrence.

Motsclés - Complexe d'Edipe, transfert, ambigü̈té, Manie, Amour.

\section{INTRODUCTION}

There are many research works on David Herbert Lawrence's concepts of human relationships, mainly on his mania or obsessive love. But the centrality of love doctrine extends even further and involves Oedipus complex and Electra complex. DH Lawrence's notion of love underpinned later ideas that love was a key element of spiritual development of a human being and that love for beautiful fellow human being (whether they are our parents or not) was the beginning of a transformative journey toward positive and negative accomplishments. 
The objective of this research work is to show and demonstrate that the virus of Oedipus complex is in every family and everywhere and can pip out at any moment in the life of individual. The choice of D. H. Lawrence's Sons and Lovesindicates that the famous history of the mythical Greek king of Thebes, the tragic hero in Greek mythology is a concern and a reality of our epoch which is permanently revisited by modern authors. We chose to highlight the concept of Oedipus complex and its consequences on the psychological development of individuals.

The objective of this research work is to show and demonstrate that the virus of Oedipus complex is in every family and everywhere and can pip out at any moment in the life our children or in our life. The choice of D. H. Lawrence's Sons and Loves indicates that the famous history of the mythical Greek king of Thebes, the tragic hero in Greek mythology is a concern and a reality of our epoch which is permanently revisited by modern authors. We chose to highlight the concept of Oedipus complex and its consequences on the psychological development of individuals.

\section{THEORETICAL FRAMEWORK AND METHODOLOGY OF THE STUDY}

To reach our goal in the purpose of this research work, we use the Classical psychoanalytic theory. This is concerned with the psychological or phenomenological aspects of thought, behavior, and experience. In classical psychoanalytic theory, the Oedipus complex occurs during the phallic stage of psychosexual development (age 3-6 years), when also occurs the formation of the libido and the ego; yet it might manifest itself at an earlier age. In the phallic stage, a boy's decisive psychosexual experience is the Oedipus complex- his son-father competition for possession of mother. It is in this third stage of psychosexual development that the child's genitalia are his or her primary erogenous zone; thus, when children become aware of their bodies, the bodies of other children, and the bodies of their parents, they gratify physical curiosity by undressing and exploring themselves, each other, and their genitals, so learning the anatomic differences between "'male"' and 'female"' and the gender differences between 'boy" and 'girl'.

\section{DESCRIPTIVE ANALYSIS OF SONS AND LOVERS}

A universally acknowledged truth is that every writer is a product of the age in which he is born and bred, and in which he works and creates. In various ways, his/her writings express his age and his/ her works cannot be understood without an understanding of the times in which he/she lives. Thus, no writer can escape the influences of his environment: social, cultural, political, and intellectual. It is also true that a critic could decide whether a work is good or bad through the psychological investigation of individual authors.

Psychology, then, comes closer to literary criticism through the psychological study of particular authors to show the relation between their attitudes and states of mind and the special qualities of their works. The special interest of autobiography depends on the eminence of the writer or on his uncommon experiences. The success of an autobiography, however, is determined largely by the degree of informality or intimacy to which the reader is admitted. Few have the moral courage to reveal all about themselves.

Lawrence was born at a mining village in Nottinghamshire. His father was a coal miner with little education; but his mother, once a school teacher was from a somewhat higher class, who came to think that she had married beneath her, and desired to raise the cultural level of her sons so as to help them escape from the life of coal miners. The conflict between the earthy, coarse, energetic but often drunk father and the refined, strong-willed and up-climbing mother is vividly presented in Sons and Lovers.

Lawrence was very close to his mother so much that even he admitted that his relationship with his mother interfered with his own relationships with women. Lawrence confessed at one point that he looked at his mother in a sexual way. His relationship with his father was very much like Paul's both young men sided with their mothers and clung to them. They hate and detested their father treated their mothers. As a young boy, he was sickly and weak and preferred to stay at home with his mother and sisters rather than play with the boys.

Lawrence was very intelligent and clever. He attended the Nottingham high School on scholarship. Later, even Jessie Chambers, whose family he was friendly with, to speak French. Lawrence became friendly with Chambers family when he and his mother began visiting their farm. Jessie was reserved and shy with him, because she felt inferior to him. The Lawrence family was impressed by Lawrence's knowledge of literature and philosophy. Lawrence cared for Jessie very deeply, but he didn't feel any attraction for her. Jessie Chambers is the 'Miriam' of Sons and Lovers. His relationship with Jessie fluctuated between love and hate; he intensely disliked the power she held over him. His sister Ada introduced him to Louise Burrows: all three of them were trained to be 
teachers at the same school. He ended his engagement with Jessie and began another one with Louise Burrows in the last days of his mother's life. His mother died on December 101, 1910; Lawrence was ill and grief-stricken for moths. Prior to his mother's death, Lawrence started to write Sons and Lovers, which he called Paul Morel first. Sons and Lovers is his most autobiographical novel; Lawrence drew upon his own memories and experiences to write the story of Paul Morel. He met Frieda von RichthofenWeekley, who was six years his senior. Frieda already married, but she run off with Lawrence to the Continent, leaving her threechildrenand husband behind. They married on July, 13, 1914. They resided in England from 1914 to 1919 because of World War I, in various towns and cities they were expelled from Corn wall in 1917 because the police.

\section{MANIFESTATION OF OEDIPUS COMPLEX IN SONS AND LOVERS}

\section{1- origin of Oedipus complex}

Sigmund Freud used the name "the Oedipus complex" to explain the origin of certain neuroses in childhood. It is defined as a male child's unconscious desire for the exclusive love of his mother. This desire includes jealousy towards the father and the unconscious wish for that parent's death, as well as the unconscious desire for sexual intercourse with the mother. Oedipus himself, as portrayed in the myth, did not suffer from this neurosis - at least, not towards Jocasta, whom he only met as an adult (if anything, such feelings would have been directed at Merope - but there is no hint of that). Freud reasoned that the ancient Greek audience, which heard the story told or saw the plays based on it, did know that Oedipus was actually killing his father and marrying his mother; the story being continually told and played therefore reflected a preoccupation with the theme.

Perhaps Sigmund Feud's most celebrated theory of sexuality; the Oedipus complex takes its name from the title character of the Greek play Oedipus Rex. In the story, Oedipus is prophesied to murder his father and have sex with his mother (and he does, though unwittingly). Freud argued that these repressed desires are present in most young boys. (The female version is called the Electra complex.)

\section{2- Oedipus complex in Sons and Lovers}

Paul is a young man with artistic talent who lives in a close-knit, English coal-mining town during the early $20^{\text {th }}$ century finds himself inhibited by his emotionally manipulative, domineering mother which is a psychological interpretation of the Oedipus story. Gertrude
Morel, miserable in her marriage, puts her hope into her son, Paul. In her attempt to manipulate Paul's life she jealously attempts to prevent Paul from having a relationship with any woman. However, Paul goes to the city for a job and becomes enchanted with self-actualized and "liberated" feminist co-worker, Mrs. Clara Dawes, who is married. Paul and Clara become involved sexually and Clara realizes that Paul's emotional attachment, as with her own, lies with another person; in Paul's case, his mother. Gertrude learns of Paul's involvement with Clara, and she ships into a morose depression and physical sickness. Paul flees to his mother, to care for her and sits by her side. After his mother's death, Paul meets the girlfriend of his youth, Miriam, and tells her that because of his co-dependency with his mother he intends to live the rest of his life without any serious relationship with another woman - in essence fulfilling his mother's desire and objective.

D.H. Lawrence was aware of Freud's theory, and Sons and Lovers famously uses the Oedipus complex as its base for exploring Paul's relationship with his mother. Paul is hopelessly devoted to his mother, and that love often borders on romantic desire. Lawrence writes many scenes between the two that go beyond the bounds of conventional mother-son love. Completing the Oedipal equation, Paul murderously hates his father and often fantasizes about his death.

\section{$\checkmark$ Sense of Guilt and incestuous feeling}

The sense of guilt and incestuous feeling is abundantly illustrated in the DH Lawrence's novel. Paul assuages his guilt and incestuous feelings by transferring them elsewhere, and the greatest receivers are Miriam and Clara,proving the concept of transference which is another Freudian term. However, Paul cannot love any other woman as much as he loveshis mother, though he does not always realize that this is an impediment to his romantic life. The aged, independent Clara, is a failed maternal substitute for Paul. In this setup, Baxter Dawes can be seen as an imposing father figure; his savage beating of Paul, then, can be viewed as Paul's unconsciously desired punishment for his guilt. Paul's eagerness to befriend Dawes once he is ill further reveals his guilt over the situation.

But Lawrence adds a twist to the Oedipus complex: Gertrude is saddled with it as well as she desires both William and Paul in near-romantic ways, and she despises all their girlfriends. She, too, engages in transference, projecting her dissatisfaction with her marriage onto her smothering love for her sons. At the end of the novel, Paul takes a major step in releasing himself from his Oedipus complex. He intentionally overdoses his 
dying mother with morphine, an act that reduces her suffering but also subverts his oedipal fate, since he does not kill his father, but his mother.

\section{$\checkmark$ The concept of transference or Replacement}

Sons and lovers is seemingly William Morel's story. But he drops dies early in the plot, which leaves us with the question of who is going to step up and paving the way to his junior brother Paul as the protagonist. Just after William dies, Paul gets really sick himself. Nursing Paul back to health distracts Mrs. Morel from the loss of William, and an intense bond is formed between Mrs. Morel and her son Paul: The two knitted together in perfect intimacy.

Mrs. Morel's life is now rooted in Paul. In other words, Mrs. Morel completely uses Paul as a replacement for her favorite son, William, illustrating the concept of transference. Such a behavior is not a good way to forge a healthy mother-son relationship. Thus, Paul becomes the new canvas for all the hopes and joys Mrs. Morel originally poured all over William. Throughout the rest of the story, Paul has to struggle against his mother's attempts to control his life, mainly with his girlfriend Miriam Leiversso that he feels terribly guilty whenever he mentions Miriam to his mother, because he knows his mother wants him to stay away from her.Paul feels good about rejecting Miriam under the pressure of his mother.

\section{$\checkmark$ The complex and ambiguous Paul's Relationship with Miriam}

In his relationship with Miriam, Paul always has trouble actually getting over the hump and allowing himself to truly love her. Several reasons are offered in the novel to show why this might be the case. Even though he knows he does love Miriam, Paul feels like he is "stupid like a child" (9.93) about the whole thing. He resists being with Miriam for reasons he can't totally explain to himself. He even wonders if he is deficient in something, though he doesn't know what exactly he is lacking. Sometimes, he thinks that it is only a sort of over strong virginity in her and him which neither could break through. But toward the end of the novel, he tells Miriam that she loves him too much and that he would "die there smothered" (15.122) if he ever committed himself to her. It clearly appears that Paul is under the influence of his mother who controls him emotionally and psychologically. He finds himself in an eternal conflict to be or not to be. Paul is an innocent victim of Mrs. Morel's revenge over her ruined marriage. Paul seems to think that Miriam is too much good for him, so he decides to try with a "more experienced woman", Clara Dawes but the experience does not work the way he thinks it could be. Clara doesn't, stimulate Paul in the same way that Miriam does.
In the end, Paul decides not to be with either Clara or Miriam. With Clara, he knows he'll never be able to give himself to her because she's only interested in the physical side of him, not the real him that is in trouble. Paul Morel is conflicted and anxious, but Clara doesn't appreciate this. Miriam, on the other hand, does appreciate the deeper part of him. But Paul is scared to give himself to her because he feels he could only give life to her by denying his own (15.136) meaning that he is afraid of losing himself in their relationship. Even though he seems totally cool with that when it comes to Mrs. Morel.

\section{CONCLUSION}

Sons and Lovers can be considered as a masterpiece among DH Lawrence literary productions as he underlined a daily challenge parents faced and are facing in our societies. To reach the goal of this research data has been collected and Freudian theory and psychoanalytic theory has been used to analyze the novel written and a conclusive analysis revealed that Oedipus complex affects negatively the child as well as the mother. Moreover, nowadays with the flourishing of unfair sexual desires approved by laws, we should try to kill children's sexual desires of their parents no to assist in a radical change whereby children will start marrying their parents.

\section{REFERENCES}

[1] Bachrach Arthur J., D. H. Lawrence in New Mexico: 'The Time is DifferentThere" Albuquerque: University of New Mexico Press, 2006.

[2] Carswell Catherine The Savage Pilgrimage. Cambridge: Cambridge University Press, 1981

[3] D. H. Lawrence Sons and Loversby. 1913

[4] Davis Joseph, D. H. Lawrence at Thirroul. Collins. 1989

[5] Delany Paul D. H. Lawrence's Nightmare: The Writer and his Circle in the Yearsof the Great War. Hassocks: Harvester Press. 1979

[6] Delavenay, Emile, D.H. Lawrence: The Man and his Work: The Formative Years, 1885-1919, trans., London: Heinemann, 1972)

[7] Foster Joseph D. H. Lawrencein Taos. Albuquerque: University of New Mexico Press. 1972.

[8] Lawrence Frieda Not I, But The Wind. Santa Fe : Rydal Press: 1934.

[9] Moore Harry T. The Priest of Love: A Life of D. H. Lawrence, Heinemann. 1974

[10] Nehls Edward D. H. Lawrence: A Composite Biography, Volumes I-III, Madison: University of Wisconsin Press, 1957

[11] Neville G.H. A. Memoir of D.H. Lawrence: The Betrayal. Cambridge University Press. 1981

[12] Nin AnaïsD. H. Lawrence: An Unprofessional Study, Athens: Swallow Press. 1963. 
[13] Raymond Caffrey T, Lady Chatterly's Lover: The Grove Press Publication of theUnexpurgated Text; Syracuse University Library Associates. 1985

[14] Witter BynnerJourney with Genius: Recollections and Reflections Concerningthe D. H. Lawrences. John Day Company, 1951.

[15] Wood Chambers E. T. Jessie D. H. Lawrence: A Personal Record, Jonathan Cape 1935 